\title{
De onstuitbare opmars van kwantitatief beleggen
}

\author{
Citation for published version (APA):
}

Kemna, A. G. Z. (1995). De onstuitbare opmars van kwantitatief beleggen. Maastricht University. https://doi.org/10.26481/spe.19950922ak

Document status and date:

Published: 22/09/1995

DOI:

10.26481/spe.19950922ak

Document Version:

Publisher's PDF, also known as Version of record

\section{Please check the document version of this publication:}

- A submitted manuscript is the version of the article upon submission and before peer-review. There can be important differences between the submitted version and the official published version of record.

People interested in the research are advised to contact the author for the final version of the publication, or visit the DOI to the publisher's website.

- The final author version and the galley proof are versions of the publication after peer review.

- The final published version features the final layout of the paper including the volume, issue and page numbers.

Link to publication

\footnotetext{
General rights rights.

- You may freely distribute the URL identifying the publication in the public portal. please follow below link for the End User Agreement:

www.umlib.nl/taverne-license

Take down policy

If you believe that this document breaches copyright please contact us at:

repository@maastrichtuniversity.nl

providing details and we will investigate your claim.
}

Copyright and moral rights for the publications made accessible in the public portal are retained by the authors and/or other copyright owners and it is a condition of accessing publications that users recognise and abide by the legal requirements associated with these

- Users may download and print one copy of any publication from the public portal for the purpose of private study or research.

- You may not further distribute the material or use it for any profit-making activity or commercial gain

If the publication is distributed under the terms of Article $25 \mathrm{fa}$ of the Dutch Copyright Act, indicated by the "Taverne" license above, 
Universitel tsbibliotheok

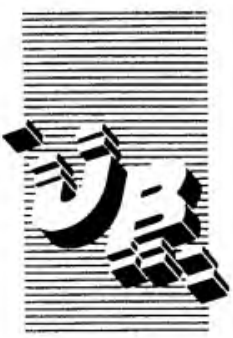

De vitleentermijn verstrijkt op:

Gelieve deze publicatie tijdig te retourneren of (telefonisch) verlenging van de vitleentermijn aan te vragen.

Rijksuniversiteit Limburg

Postbus 616

6200 MD Maastricht 


\section{DE ONSTUITBARE OPMARS VAN KWANTITATIEF BELEGGEN}

Dr A.G.Z. Kemna 



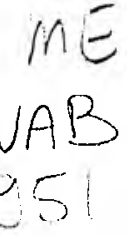

\section{DE ONSTUITBARE OPMARS VAN KWANTITATIEF BELEGGEN}

Rede

in verkorte vorm uitgesproken bij de aanvaarding van het ambt van gewoon hoogleraar Financieel Management en

Financiële Markten aan de Rijksuniversiteit Limburg op vrijdag 22 september 1995

door

Dr A.G.Z. Kemna 
(1) 1995 Institute for Research and Investment Services BV, een gezamenlijke ondememing van Rabobank Nederland en Robeco Groep Postbus 1296, 3000 BG Rotterdam. Nederland

Alle rechten voorbehouden. Niets uit deze uitgave mag worden verveelvoudigd, opgeslagen in een geautomatiseerd gegevensbestand, of openbaar gemaakt, in enige vorm en op enige wijze, zonder voorafgaande schriftelijke toestemming van de uitgever.

CIP-GEGEVENS KONINKLIJKE BIBLIOTHEEK, DEN HAAG

Kemna. A.G.Z.

De onstuitbare opmars van kwantitatief beleggen / A.G.Z. Kemna. Rolterdam: Institute for Research and Investment Services - III Inaugurele rede Rijksuniversiteit Limburg, Mastricht. Met lit. opg. ISBN 90-802745-1-8

NUGI 681

Trefwoord: beleggen. 
Mijnheer de Rector Magnificus,

Dames en heren, 
$P=140.93629$

Universiteitsbibliotheek

Rijksunivarsiteit Lirabur? 


\section{Inleiding}

In de wondere wereld van het beleggen, die er de laatste jaren alleen nog maar exotischer op is geworden, is kwantitatief portefeuillemanagement aan een onstuitbare opmars bezig. Vroeger - in de jaren zestig - bestond het beleggen uitsluitend uit het selecteren van 'geschikte' aandelen - aandelen waarvan men verwachtte dat ze een positief rendement zouden opleveren. Van een systematische vergelijking met andere aandelen was nauwelijks sprake. Men hield deze aandelen doorgaans lange tijd in portefeuille. Van conjuncturele fluctuaties trok men zich weinig aan en een bewuste allocatie over landen vond niet plaats. Pas in de jaren zeventig toen de rente in de westerse landen verdubbelde, kwam hierin verandering.

De informatie over fondsen, die een internationale belegger in die tijd verkreeg, werd bepaald door het toeval. Effectenmakelaars die met 'gouden tips' of koopjes kwamen aandragen vormden de basis voor de selecties die werden gemaakt. Een waargebeurd voorval is het verhaal van een Nederlandse belegger die een tip kreeg van zijn Franse effectenmakelaar over een interessant groeifonds. De effectenmakelaar motiveerde zijn keuze door zijn ongenoegen te uiten over het feit dat de secretaresses niet meer wilden meelunchen: zij aten liever de yoghurt van dat Franse groeifonds met het oog op hun lijn. En als een Française haar lunch hiervoor opgeeft, dan moest het wel een interessant fonds zijn.

Inmiddels is de situatie volledig veranderd. Een positief beleggingsresultaat is niet langer voldoende. Aandelen worden alleen gekocht als men denkt dat ze beter zullen renderen dan het gemiddelde van de markt. Conjuncturele fluctuaties van de economie spelen een veel grotere rol in het beleggingsbeleid. En via de zogenoemde 'top-down' benadering kiest de professionele internationale belegger eerst in welke landen hij of zij wil beleggen en maakt dan pas de aandelenkeuze.

Gevoed door wetenschappelijke bevindingen zijn de eisen van de klant in de loop van de tijd ook aangescherpt: er wordt geen genoegen meer genomen met een op 'Fingerspitzengefühl' uitgevoerde wijze van beleggen. Het actieve beleggingsproces moet transparant zijn en op consistente wijze worden uitgevoerd.' Dit geldt zowel voor de doelen dic behaald dienen te worden met actief beleggen, alsmede de weg waarlangs men deze doelen denkt te verwezenlijken. En bij een meer gestructureerde manier van ac-

1 In Amott (1988, 1994) en Amott and Henriksson (1989) wordt een overzicht gegeven over heden en toekomst van het kwantitatief beleggingsproces. 
tief beleggen ontkomt men er niet aan het beleggingsbeslissingsproces te laten ondersteunen door kwantitatieve methoden en technicken. En dat heeft automatisch geleid tot het ontstaan van een meer kwantitatief gericht portefeuillemanagement.

Niet alleen de aard van het beleggen is veranderd, maar ook de instrumenten waarmee kan worden belegd.

Vroeger waren er slechts enkele internationaal beleggende instellingen; tegenwoordig is het heel gewoon de wereld als één markt te zien. Met behulp van afgeleide instrumenten zoals futures en opties is het mogelijk om relatief snel en goedkoop het belang in een bepaald land op of af te bouwen zonder het fysiek uitruilen van aandelen of obligaties. Met deze instrumenten is het voor de recentelijk aanwezige 'hedge funds' zoals die van George Soros mogelijk om relatief veel invloed op de financiële markten uit te oefenen.

Met de opmars van het kwantitatief beleggen is er een veelheid van modellen ontstaan. Voordat we uitgebreid ingaan op welke modellen op welke wijze bij het kwantitatief beleggen worden gebruikt, is het zinvol stil te staan bij hetgeen nu eigenlijk onder een model wordt verstaan. Volgens Van Dale is "iemand die poseert voor een kunstenaar; iemand die daar zijn of haar beroep van maakt" een voorbeeld van een model. ${ }^{2}$ Een afbeelding van de Chippendales geeft precies aan wat modellen voorstellen; een zeer fraaie weergave van, in dit toevallige geval, het mannelijke geslacht. Toch zullen er in de realiteit niet veel mensen zijn die exact aan dit ideaalbeeld voldoen. In die zin vormt elk model een gestyleerde representatie van de realiteit en op die manier heeft het ook een functie. Dit geldt voor kwantitatieve modellen net zo, zoals $u$ in het verloop van mijn betoog zult vernemen.

De ontwikkeling van een meer kwalitatief gericht beleggingsproces naar een meer kwantitatief gericht beleggingsproces is hand in hand gegaan met de ontwikkeling op het gebied van de financiële modelbouw.

De in de praktijk gehanteerde modellen kunnen grofweg in drie categorieèn worden ingedeeld:

2 Dit idee heb ik opgedaan tijdens een van de eerste colleges van Alexander Rinnooy Kan over bedrijfsmodellen aan de Erasmus Universiteit te Rotterdam. 


\section{Voorspelmodellen}

Deze modellen hebben als doel het rendement van beleggingsobjecten te voorspellen teneinde een hoger beleggingsresultaat te kunnen behalen.

\section{Portefeuille-allocatiemodellen}

Deze modellen hebben als doel om de verwachtingen ten aanzien van de beleggingsobjecten te vertalen naar portefeuillegewichten, rekening houdend met klantspecifieke doelstellingen.

\section{Prijsvormingsmodellen van afgeleide instrumenten}

Deze modellen hebben als doel de prijs en de risico's van de afgeleide instrumenten zo exact mogelijk te meten.

Hoewel er bij de ontwikkeling van prijsvormingsmodellen van afgeleide instrumenten zeker sprake is van een onstuitbare opmars, is er weinig verschil van mening over de wijze waarop deze modellen in de praktijk moeten worden gebruikt. Wel is er discussie over of en hoe derivaten in cen beleggingsportefeuille mogen worden gehanteerd. Aangezien daar de laatste tijd al veel over is gezegd en de autoriteiten met hun regelgeving de goede weg lijken in te slaan, wil ik hier nu niet verder op ingaan. Aangezien bij de eerste twee soorten modellen wel verschil van inzicht bestaat over de rol die zij spelen binnen het beleggingsproces wil ik hierover vanmiddag mijn ideeën uiteenzetten.

De titel van mijn rede bevat een waardeoordeel dat wellicht door menigeen als provocerend wordt ervaren; het is ook de bedoeling om duidelijk stelling te nemen ten aanzien van de ontwikkeling en het gebruik van kwantitatief beleggen in een weerbarstige werkelijkheid. Vandaag ben ik in de gelegenheid deze titel toe te lichten en te onderbouwen. Eerst zal ik een theoretische motivatie geven voor het bestaansrecht van een meer kwantitatief onderbouwde wijze van actief beleggen. Vervolgens zal ik uiteenzetten welke kwantitatieve modellen hierbij een rol spelen - en waar hun grenzen liggen - en hoe de relatie ligt ten opzichte van de inbreng van beleggers. Tot slot wil ik aangeven wat de consequenties van deze stormachtige ontwikkeling zijn voor het financiële onderwijs en onderzoek. 


\section{2. 'Can we beat the market?'}

Een vraag die beleggers voortdurend bezighoudt is of het mogelijk is om systematisch de markt te verslaan. Dat wil zeggen dat wordt getracht met actief portefeuillebeheer voondurend een hoger rendement te behalen dan het gemiddelde van de markt. Lange tijd dacht men dat de professionele belegger daartoc in staat was door op basis van zogenoemde fundamentele en technische informatie de juiste aandelen ('stock picking') op het juiste moment ('timing') te selecteren.

Echter, uitgaande van de theorie van de efficiënte markten [Fama (1970)] - deze wil zeggen dat alle beschikbare (fundamentele en technische) informatie meteen in de aandelenprijzen wordt gereflecteerd - leck het onmogelijk jaar in jaar uit de markt te verslaan. Deze stelling komt voort uit het bekende prijsvormingsmodel voor aandelen - het Capital Asset Pricing Model (CAPM). ${ }^{3}$ Dit simpele model gaat ervan uit dat beleggers rationeel zijn en gelijke verwachtingen over de toekomstige aandelenrendementen hebben, hetgeen resulteert in één verwachte evenwichtprijs ('Rational Expectations Equilibrium').

En inderdaad werd door middel van empirisch onderzock aangetoond dat niemand systematisch in staat was meer rendement te behalen op een aktief beheerde portefeuille dan het rendement dat werd behaald op cen aandelen-index. ${ }^{4}$ Hiermee leek de toegevoegde waarde van aktief beleggen verdwenen en werd de deur geopend voor passief of index-beleggen. Passief beleggen heeft als doel zodanig te beleggen dat het rendement op een index zo goed mogelijk wordt gevolgd tegen zo laag mogelijke kosten ('index (racking').

Maar inmiddels is het tij weer gekcerd. Onlangs verscheen in Fortume (april 1995) een populair artikel met de uitdagende kop: 'Yes, you can beat the market'. Hierin werd de geldigheid van de efficiënte markthypothese door langdurig succesvolle beleggers in twijfel getrokken en terecht: op basis van empirisch onderzoek zijn de laatste paar jaren scheuren, zo niet barsten, ontstaan in het efficiënte-marktenbolwerk.

3 Van onder andere Sharpe (1964).

+ Zie bijvoorbeeld Fama and MacBeth (1973) in een meer theoretische setting en Brinson, Hood and Beebower (1986) in een meer praktische setting. 
Door de portefeuille tijdelijk sterk uit te breiden in januari, of te beleggen in kleine ondernemingen of in ondernemingen met een lage koers/winst verhouding bleek het wel degelijk mogelijk systematisch overwinsten te behalen. ${ }^{5}$ Daarnaast bleken de extreme koersfluctuaties, die in de aandelenmarkt bestaan, onverklaarbaar op basis van het eenvoudige CAPM [Shiller (1981)]. Het evenwichtsmodel dat zelfs cen Nobelprijswinnaar heeft opgeleverd lijkt na dertig jaar versleten en toe aan vervanging.

Het is dan ook de hoogste tijd dat er enig theoretisch kader wordt geschapen, waarmee de empirisch gevonden relaties wel kunnen worden verklaard. Toonaangevend in dit verband is momenteel de theorie van Mordecai Kurz (1994). Uit het feit dat in dezelfde Fortune zijn idecën worden geciteerd blijkt dat beleggers in de praktijk al op de hoogte zijn van zijn denkbeelden. Dat geeft al aan dat voor beleggers hieraan belangrijke implicaties zijn verbonden. Bovendien leert de theorie van Kurz ons iets over het nut en de beperkingen van modellen binnen actief portefeuillemanagement.

Essentieel in de theorie van Kurz - en zo herkenbaar in de praktijk - is dat beleggers verschillende gedachten kunnen hebben ten aanzien van toekomstige gebeurtenissen, hoewel ze uitgaan van dezelfde informatic. Dit is een belangrijke tegenstelling ten opzichte van het CAPM, waar slechts één interpretatie van de beschikbare informatie mogelijk is. Het verschil in interpretatie ontstaat uit verschillende wijzen van denken over de werking van de economie. Zo blijkt dat een verschil in aantal jaren beleggerservaring op zich al kan leiden tot een verschil in mening over de vooruitzichten van een bepaald aandeel.

Kurz laat aldus zien dat meerdere interpretaties van dezelfde informatie niet betekent dat beleggers irrationeel zijn. Er kunnen meerdere rationele interpretaties bestaan van dezelfde data. Dit leidt in de praktijk tot een prijsevenwicht dat wel wordt aangeduid als een 'Rational Beliefs Equilibrium'. Dit in tegenstelling tot het CAPM, hetgeen leidt tot een 'Rational Expectations Equilibrium'.

In Figuur 1 is schematisch weergegeven hoe de prijzen tot stand komen in beide evenwichten. Zoals blijkt uit de figuur staat Kurz meerdere 'modellen' toe, die leiden tot verschillende voorspellingen van de prijzen op financiële markten. Door de verschillen in voorspelde prijzen ontstaat er handel, alsmede een bepaalde prijs waartegen wordt gehandeld.

5 Zie o.a. Banz (1981), Reinganum (1981), Copeland and Mayers (1982), VandenBergh and Wessels (1985), DeBondt en Thaler (1985), Jaffe, Keim and Westerfield (1989), DeJong. Kemna and Kloek (1992), Fama and French (1992), Lakonishok, Shleifer and Vishny (1994). 
Figuur 1. Evenwichtsmodellen

Rational Expectations Equilibrium

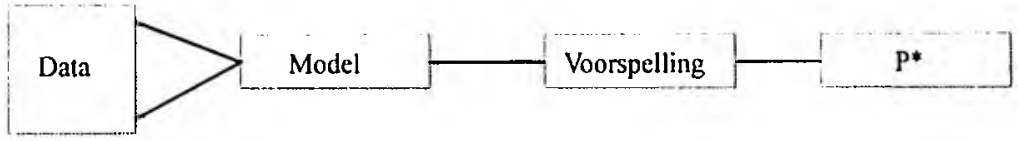

Rational Beliefs Equilibrium

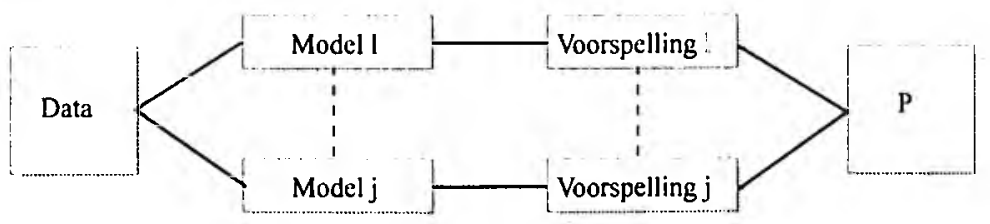

De 'Rational Beliefs' theorie heeft belangrijke gevolgen voor de praktijk van het beleggen. Ten eerste, de conclusie dat het wel degelijk mogelijk is om via actief management de markt systematisch te verslaan. Hoewel beleggers in deze theorie wel rationeel denken, kunnen zij geen exact correcte voorspelling van de toekomst maken en zijn daardoor bereid uiteenlopende prijzen te betalen voor hetzelfde beleggingsobject. De belegger die in staat is om de beste gevolgtrekkingen uit de informatie te maken is ook in staat de markt te verslaan. Maar de theorie van Kurz geeft aan dat modellen alleen hiervoor nooit tocreikend kunnen zijn. Diegenen die beter dan de rest in staat zijn structurele veranderingen tijdig te herkennen zullen mogelijk de markt kunnen verslaan. Een citaat van Kurz uit het Fortumeartikel is illustratief voor deze stelling: "It's not that people are stupid. It's that most people fail to perceive structural changes in the economy that affect stock prices. They invest in yesterday's winners instead of tomorrow's." George Soros - overigens op de hoogte van de theorie van KurZ - is een bekend voorbeeld van een belegger die uit een betere interpretatie van de werkelijkheid dan anderen zijn slag probeert te slaan.

Een tweede implicatie is dat deze theorie een beter begrip geeft van de beweeglijkheid van de markt zoals die in de praktijk wordt waargenomen. Doordat er meerdere interpretaties bestaan over de toekomst is er beweging in de markt zonder dat er noodzakelijkerwijs sprake is van nieuwe informatie. Binnen deze theorie hebben extreme koersstijgingen en -dalingen ('bubbles' en 'crashes') dan ook een plaats. Bovendien is de theorie 
zo elegant, omdat hierin het CAPM niet wordt verworpen, maar meer wordt gezien als een speciaal geval. Dat betekent dus niet dat de wereld van het CAPM geheel fout is, maar meer een te simpele voorstelling van zaken.

Een derde implicatie is dat, op basis van deze theorie, er binnen het kwantitatieve beleggingsproces weer plaats is voor een kwalitatieve interpretatie van de werkelijkheid. Dit heeft gevolgen voor het gebruik van kwantitatieve modellen. Enerzijds moet continu worden gezocht naar modellen die zo goed mogelijk in staat zijn met de beschikbare informatie te voorspellen: onze weerbarstige werkelijkheid is aan verandering onderhevig, evenals de wetenschappelijke inzichten in methoden en technieken en dat verdient creativiteit en alertheid van de modelbouwer om tijdig modellen aan te passen. Anderzijds moet de belegger zo goed mogelijk geïnformeerd worden over de kracht en de beperkingen van het model, zodat hij of zij in staat is de waarde van het model in te schatten.

Als de belegger denkt aan de vooravond te staan van een structurele verandering op de financiële markten zullen de aanbevelingen van het model minder relevant zijn dan wanneer het tij nog niet aan het keren is. De EMS-crisis werd niet door kwantitatieve modellen voorspeld. Ook gaven de modellen niet aan - toen de crisis er eenmaal was - wat de gevolgen ervan zouden zijn. Bij dat soort grote onverwachte gebeurtenissen laten modellen ons in de steek. Hier komt de kennis en kunde van de belegger om de hoek kijken. Het is belangrijk te realiseren dat dit de kracht is van de belegger en dat modellen hier weinig tot geen functie hebben; de functie van het model moet zijn dat men over de dingen die bekend zijn - dit omvat ook consensus verwachtingen - een duidelijk beeld heeft. Dit vormt een uitgangspunt om verder te denken. Dit wil ik toelichten aan de hand van de twee eerder genoemde soorten modellen: voorspelmodellen en portefeuille-allocatiemodellen. 


\section{Voorspelmodellen}

In de wetenschappelijke literatuur zijn onder andere voorspelmodellen terug te vinden die de keuze tussen verschillende aandelen en de keuze tussen verschillende landen ondersteunen. ${ }^{6}$ Deze modellen zijn ontwikkeld op basis van inzichten uit theorie en praktijk. Als input voor de modellen geldt de fundamentele en technische informatie over een onderneming, bedrijfstak of de gehele economie - informatie die een 'gewone' kwalitaticve belegger ook zou gebruiken.?

Voor de wetenschappelijke wereld waren voorspelmodellen om aandelen te selecteren schokkend. Lange tijd dacht men dat het risico van een aandeel exclusief bepalend was voor de hoogte van het rendement. Hoe hoger het risico, hoe hoger het rendement. Inmiddels heeft de wetenschap onderkend dat er ook andere variabelen meespelen zoals koers/winst-verhouding, omvang, dividendrendement en momentum [Fama and French (1992)]. Dit was overigens voor beleggers uit de praktijk al sinds 1934 bekend. Zij vormden het selecte groepje 'waarde'-beleggers rondom Graham en Dodd (1934). Waardebeleggers gaan ervan uit dat superieure beleggingsresultaten kunnen worden behaald door juist de zwakke broeders onder de aandelen te kopen - ondernemingen met bijvoorbeeld een lage koers/winst-verhouding, of lage historische rendementen - en deze voor de lange termijn aan te houden.

De reden om deze tegendraadse ('contrarian') strategie te propageren is afkomstig uit de psychologie: door de neiging naïef te extrapoleren zijn beleggers vaak veel te negatief voor zwakke aandelen en veel te positief voor 'glamour' aandelen - aandelen die al veel in waarde zijn gestegen.

6 DeBondt and Thaler (1985), Capaul, Rowley and Shape (1993), Lakonishok, Shleifer and Vishny (1994) voor individuele aandelen en Solnik (1993), Ferson and Harvey (1991,1994) en Harvey, Solnik and Zhou (1994) voor landen.

7 Als sommige modellen uitsluitend fundamentele of technische informatic bevatten, is dat een gevolg van een beter econometrisch verband en niet zozeer vanwege de verschillen in inzichten die bestaan tussen fundamentee] en technisch analisten. Bij een korte beleggingshorizon zal informatic afkomstig uit de technische analyse vaker succesvol zijn voor het voorspellen van het korte-termijnrendement, terwijl bij een langere beleggingshorizon veelal de fundamentele informatie de overhand zal hebben. 
Hierdoor zijn de zogenaamde 'slechte' aandelen ondergewaardeerd en de 'goede' aandelen overgewaardeerd. Dit en ander gedrag van mensen en in het bijzonder van beleggers is onderzoeksobject van een nieuwe richting in de beleggingstheorie en staat bekend als 'Behavioral Finance'. 8

Als we de Fortune (april 1995) mogen geloven, blijkt de waardestrategie in de praktijk een strategie die langdurig tot superieure resultaten heeft geleid: "What makes these successful investors particularly interesting is that their good fortune is not uniformly attributable to extraordinary brilliance - though they are certainly smart - but more to the principles of value investing, which anyone with a solid grasp of high school mathematics can learn." De vraag is dan waarom niet iedereen deze strategie toepast. Het argument dat Lakonishok e.a. (1994) geven is dat voor de meeste fondsbeheerders deze tegendraadse strategie moeilijk te verkopen is aan hun klant: de geselecteerde waarde-aandelen zien er niet goed uit en stel dat het op enig moment toch niet goed gaat met de portefeuille, dan verschuilt men zich toch liever achter de slechte performance van 'glamour' aandelen dan achter die van 'losers'. Met de woorden van Keynes (1936, blz. 158): "worldly wisdom teaches that it is better for reputation to fail conventionally than to succeed unconventionally" in het achterhoofd worden door deze fondsbeheerders waarde-aandelen niet gekocht.

Er zijn dus verschillende opvattingen over welke aandelen het meest te prefereren zijn. Dit kan zijn veroorzaakt door een ongelijke economische, sociale of psychologische achtergrond van de spelers op de financiële markten. Daardoor ontstaan er meedere interpretaties van de beschikbare informatie, hetgeen leidt tot een verschil in prijs die men bereid is te betalen voor een aandeel. In die zin past dit soort strategieën binnen het theoretische raamwerk van de 'Rational Beliefs' theorie van Kurz.

Niet alleen ten aanzien van selectie van individuele aandelen zijn aansprekende resultaten beschikbaar. Recentelijk is ook bewijs gekomen uit de wetenschappelijke wereld dat de rendementen van landen (aandelen en obligaties) enigszins voorspelbaar zijn met behulp van bekende informatie. Indien het beleggingsproces volgens een 'top-down' benadering is gestructureerd dan vormt de landenallocatie na de asset allocatie de belangrijkste beslissing. Daarom kunnen deze voorspelmodellen een aantrekkelijke ondersteuning voor de landenbelegger zijn.

y In DeBondt and Thaler (1994) wordt een uitstekend overzicht gegeven van de ontwikkelingen op het gebied van de 'Behavioral Finance', waarin expliciet rekening wordt gehouden met de consequenties van het waargenomen gedrag van mensen op de prijsvorming op financiële markten. Hierin worden concepten uit de psychologie gebruikt. 
Bij het ontwikkelen van $k$ wantitatieve methoden voor landenallocatie wreekt zich het verschil tussen theoric en praktijk; voor de wetenschap is niet zozeer van belang welke informatie exact wordt gebruikt, maar gaat het meer om de ontwikkeling van elegante theoretische concepten en de hantering van de laatste econometrische technieken. Voor de praktijk is het nodig dat niet te ingewikkeld wordt gedaan, maar dat juist de variabelen dic relevant worden geacht voor de landenallocatie uitvoerig worden onderzocht. Het is de kunst om gezamenlijk te komen tot een voor beide partijen aanvaardbare methodiek; aanvalardbaar in de zin dat voldaan is aan beider minimale eisen voor een model.

In de praktijk blijkt dat het moeilijk is om voor de landenallocatie van een aandelenportefeuille een voldoende betrouwbaar voorspelmodel te genereren. In plaats daarvan is het ook mogelijk de stap van de landenallocatie achterwege te laten. Dat zou betckenen dat aandelenselectie over een aantal landen tezamen - bijvoorbeeld Europa - plaatsvindt. Dit is alleen interessant als de modellen voor de aandelenselectie over landen heen even goed blijven werken als voor een individueel land: eerste praktische resultaten geven aan dat ze over landen heen zelfs beter werken. Deze zogenoemde 'bottom-up' benadering zou in de toekomst wel eens een grote rol kunnen gaan spelen binnen het beleggingsproces en geeft aanleiding tot aantrekkelijk praktijkgericht onderzoek.

Geheel in de lijn met de ideeën van Kurz kunnen bovenstaande theoretische voorspelmodellen gebruikt worden om adviezen ten aanzien van aandelen- of landenselectie te geven. Het gebeurt echter nogal eens dat deze adviezen met grote overtuigingskracht worden gepresenteerd, omdat men het idee heeft dat dit de enige manier is om te proberen icts te veranderen in de traditionele wijze van beleggen. Hoewel bekend is dat het moeilijk is om met de traditionele manier van beleggen superieure resultaten te behalen, worden aan kwantitatief gegenereerde adviezen wel dergelijke, onrealistische, eisen gesteld. En om aan die eisen te voldoen is het risico groot dat de resultaten die in het verleden behaald zijn mooier worden voorgesteld dan men in de toekomst zou kunnen verwachten." Dat kan leiden tot onjuist gebruik van modellen en dan ligt de teleurstelling en verwerping ervan op de loer.

9 Lo en MacKinley (1990) laten zien hoe resultaten door 'datasnooping' mooier kunnen lijken, dan ze in werkelijkheid kunnen worden waargemaakt. 
Gedenkwaardig in dit verband zijn de woorden van Niccolò Machiavelli [De heerser, blz 76] "Men dient namelijk voor ogen te houden dat niets qua voorbereiding moeilijker, qua succes twijfelachtiger en qua uitwerking gevaarlijker is dan zich opwerpen als iemand die vernieuwingen wil doorvoeren. Want hij die dat doet, heeft hen die van de oude toestand profiteren tot vijanden, terwijl hij slechts lauwe verdedigers vindt in hen dic van de nieuwe toestand zouden kunnen profiteren...".

Het is overdreven om te verwachten dat met modelmatige adviezen wel te allen tijde goed kan worden gepresteerd. Hoewel er best aansprekende beleggingsresultaten te behalen zijn met het gebruik van kwantitatieve modellen sec, is het uitgangspunt van deze modellen een 'stationaire' voorspelling zonder structurele veranderingen. Het model is in de ogen van Kurz maar de helft van het beleggingsproces; de andere helft wordt gevormd door de ideeën van de belegger omtrent mogelijke structurcle veranderingen. 


\section{Van verwachtingen naar portefeuille-allocatie}

De voorspellende modellen geven de belegger een, met meer of minder onzekerheid omgeven, uitspraak over verwachte rendementen. ${ }^{10}$ Als we eenmaal weten hoe we over de toekomst van beleggingsobjecten denken, dan komen portefeuille-allocatiemodellen om de hoek kijken." Immers, alle inzichten moeten op de een of de andere manier worden vertaald naar een concrete samenstelling van de beleggingsportefeuille. Aangezien individuele klanten specifieke eisen stellen aan de portefeuille, is er behoefte ontstaan aan ondersteunende modellen die rekening konden houden met die eisen. Voorbeelden van die eisen zijn: een voldoende gespreide portefeuille al dan niet ten opzichte van een benchmark, regionale grenzen, duration-restricties, omzetrestricties. Sommige eisen zijn gevoed door inzichten uit de theorie, sommige zijn ontstaan door praktische overwegingen.

Het meest bekende model waarmee het portefeuille-allocatieprobleem inzichtelijk wordt gemaakt is het optimalisatiemodel van Markowitz (1959). Zoals zo vaak het geval is in de financiële wereld vond een knappe kop uit een andere discipline een briljante toepassing voor zijn kwadratisch programmeringsmodel. Hij zocht en hij vond al in de jaren vijftig een manier om portefeuilles samen te stellen die, gegeven een bepaald verwacht rendement, minimaal verwacht risico opleverden; de perfecte, en Nobelprijs opleverende, toepassing van een leuk model. Voor sommigen is het model wel bekend, voor anderen niet. Daarom wil ik kort uitleggen hoe het werkt.

Op basis van gegevens over het verwacht rendement en risico van meerdere beleggingsobjecten kan een serie optimale portefeuilles worden berekend die wat betreft de verhouding tussen risico en rendement niet te verbeteren zijn. ${ }^{12}$ Dat wil zeggen dat er in de verwachting geen portefeuilles bestaan die meer rendement opleveren met een gelijk risico of die minder risico opleveren met een gelijk rendement. Afhankelijk van de risicohouding van de belegger in kwestie kan dan een bepaalde portefeuille worden gekozen.

10 De 'alfa's' kunnen verschillen afhankelijk van de beleggingshorizon; het is denkbaar dat gespeeld wordt op tegelijkertijd de kone- en lange-termijnvoorspelling [zie Arnott (1994)].

"Ook de modellen die worden ontwikkeld ter ondersteuning van het Asset Liability Management vallen onder deze categorie. Hoewel dit wellicht een van de meest succesvolle voorbeelden is van deze categorie modellen in Nederland, wil ik er verder niet op ingaan, mede in de verwachting dat anderen dat binnenkort zullen doen.

12 Het resultaat van de optimalisatie is te beleggen hoeveelheden in de beleggingsobjecten. 
Helaas, en dat gebeurt ook maar al te vaak, bleck dat de praktijk veel problemen had met de toepassing van dit model. Eigenlijk is de ellende begonnen omdat men dit model niet als beleggingsondersteunend zag, maar meer als 'black-box', waaruit voor beleggers voorschriften volgen. Deze risico-minimaliserende 'black-box' was voor de belegger moeilijk te verteren, omdat juist de taak van een belegger is het nemen van risico door te zoeken naar de meest aantrekkelijke beleggingsobjecten.

Vergelijk het maar eens met het zoeken naar een nieuwe woning. U oriënteert zich door rond te rijden in de door uw gewenste omgeving op zock naar bordjes 'te koop'. Daarmee hoopt u een indruk te krijgen van de hoeveelheid en het soort huizen dat te koop staat. Dan stelt u zich in verbinding met een plaatselijke makelaar en legt hem het probleem voor. Nadat u de maximale koopsom heeft opgegeven, geeft de makelaar u een partij foto's van het 'bovenaanzicht' van de relevante huizen. Hij legt uit dat de beste keuze gemaakt kan worden op basis van het bovenaanzicht van het huis, omdat $u$ dan veel beter in één keer overzicht zou hebben over de lengte en breedte van het huis. Dat mag wel zo zijn, maar het is niet de manier waarop u er zelf tegenaan kijkt. U wilt liever foto's van het 'vooraanzichl' van een huis om zo breedte en hoogte te kunnen zien. En hoewel het om hetzelfde huis gaat, en het dus in principe niet uitmaakt, zult u toch geneigd zijn een andere makelaar te zoeken met de voor $u$ optimale oplossing van het probleem.

Het veranderen van de dimensie van het probleem kan ook succesvol worden toegepast op het oorspronkelijke model van Markowitz. In plaats van het probleem te formuleren als het minimaliseren van het risico gegeven een verwacht rendement, blijkt het veel aansprekender te zijn om het verwachte rendement te maximaliseren gegeven een bepaald risiconiveau. Op deze manier ziet de belegger direct dat de beleggingsobjecten waarvoor hij of zij het meest positief is, worden beloond doordat die een relatief groot portefeuillegewicht verkrijgen. Dat er voor de spreiding binnen de portefeuille nog enkele beleggingsobjecten moeten worden toegevoegd met een zo laag mogelijk gewicht is dan voor de belegger heel acceptabel. Hieruit blijkt eens te meer dat het gebruik van beleggingsmodellen zoveel mogelijk moet aansluiten op de wijze waarop beslissingen worden genomen in de realiteit en dat het geen zin heeft beleggers een andere realiteit op te leggen. ${ }^{13}$

13 Een van de pogingen hiertoe komt van Shefrin and Staunan (1994) die een portefeuilleallocatietheorie opzetten met als uitgangspunt het waargenomen 'behavioral' handelen van beleggers. 
Hoewel de herformulering van het model heeft geleid tot acceptatie van het model als zodanig, blijken de resultaten die volgen uit het model uiterst gevoelig te zijn voor de wijze waarop de gegevens worden aangeboden. ${ }^{14}$ Zo kunnen kleine verschillen in verwachte rendementen tot grote verschillen in portefeuillegewichten leiden, terwijl de voorspelfout van diezelfde verwachtingen vaak zo groot is dat zulke grote verschillen in gewichten niet gerechtvaardigd zijn. Helaas is echter nog weinig bekend over de 'beste' wijze waarop verwachte rendementen moeten worden aangeboden aan dit model, of hoe rekening moet worden gehouden met instabiliteit van het voorspelmodel.

Het is eigenlijk onbegrijpelijk hoezeer de theorie hier de praktijk in de steek laat. Er wordt veel tijd gestoken in de ontwikkeling van voorspelmodellen, maar er wordt amper ingegaan op de problemen die ontstaan wanneer een strategie op basis van een voorspelmodel moet worden toegepast op werkelijke portefeuilles. ${ }^{15}$ Immers, de portefeuille die wordt geadviseerd is sterk afhankelijk van hetgeen er door de belegger zelf is ingestopt en dat is aan onzekerheid onderhevig. Om aan het bezwaar van de gevoeligheid van de input tegemoet te komen, moet het mogelijk zijn om een gevoeligheidsanalyse toe te passen binnen het allocatiemodel. Daarmee wordt inzicht verkregen in hoeverre de portefeuille-allocatie gevoelig is voor kleine veranderingen in de gebruikte informatie.

De voorspel-en portefeuille-allocatiemodellen vormen de basisingrediënten van het kwantitatieve beleggen. Voor beide geldt dat ze geen 'black-box' mogen vormen, waarvan de uitkomsten blind worden toegepast. De modellen vormen instrumenten, waarmee het beleggingsproces meer gestructureerd en gedisciplineerd kan verlopen. In figuur 2 laat ik zien hoe het kwantitatieve beleggingsproces verloopt.

\section{Figuur 2. Kwantitatief beleggingsproces}

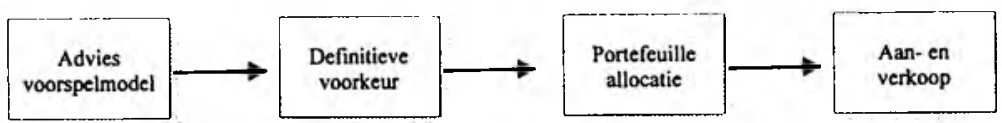

14 Zie bijvoorbeeld Michaud (1989) en Chopra and Ziemba (1993).

15 In het artikel van Ball, Kothari and Shanken (1995) wordt er wel op gewezen dat bij het handelen tegen marktprijzen met name bij tegendraadse strategieën nogal wat rendement verloren kan gaan vanwege de hoge bied-laatspreiding bij de relatief lage prijzen van waarde-aandelen. 
De voorspelmodellen hebben een meer of minder betrouwbaar advies voor de belegger als resultaat. De mate van betrouwbaarheid hangt enerzijds af van de voorspelkracht van het model en anderzijds van de verwachte onzekerheid in de toekomst. De belegger gaat gewapend met dit advies na of er op dit moment reden is om het advies te volgen of niet. Dit leidt tot een definitieve voorkeur voor beleggingsobjecten. Vervolgens wordt met verstand een portefeuille-allocatiemodel gehanteerd om te komen tot de portefeuillesamenstelling.

Afhankelijk van de huidige portefeuille leidt dit tot de uiteindelijke aan- of verkoop binnen de portefeuille. Concluderend, is naar mijn mening hel kwantitatieve beleggen een proces, waarbinnen ruimte is voor een vruchtbare samenwerking tussen kwantitatieve methoden en technieken en kwalitatieve inzichten van de belegger. Begrip en toenadering zullen nodig zijn om maximaal resultaat te kunnen behalen. 


\section{Consequenties voor financieel onderzoek en onderwijs}

De opkomst van kwantitatieve beleggingsmethoden en -technieken heeft ook gevolgen voor het academisch onderzock en onderwijs. De eisen dic aan beleggers worden gesteld zijn als gevolg van deze nieuwe methoden en technieken steeds hoger geworden. Van pas afgestudeerden wordt niet alleen uitstekende theoretische kennis verwacht, maar ook praktisch inlevingsvermogen. Dat vraagt om een grote mate van flexibiliteit en modulariteit binnen het financiële opleidingstraject met een gestructureerde mate van interactie tussen theorie en praktijk. Het is mij cen eer daar met mijn leeropdracht 'Financieel Management en Financiële Markten' aan bij te dragen.

Om te illustreren hoczeer de kennis over financiële markten multi-disciplinair is geworden, heb ik in figuur 3 een grafische representatie gegeven van de rijke gevaricerdheid van modellen binnen de beleggingswereld. ${ }^{16}$

Figunr 3. Overzicht van relevante disciplines voor financiële markten

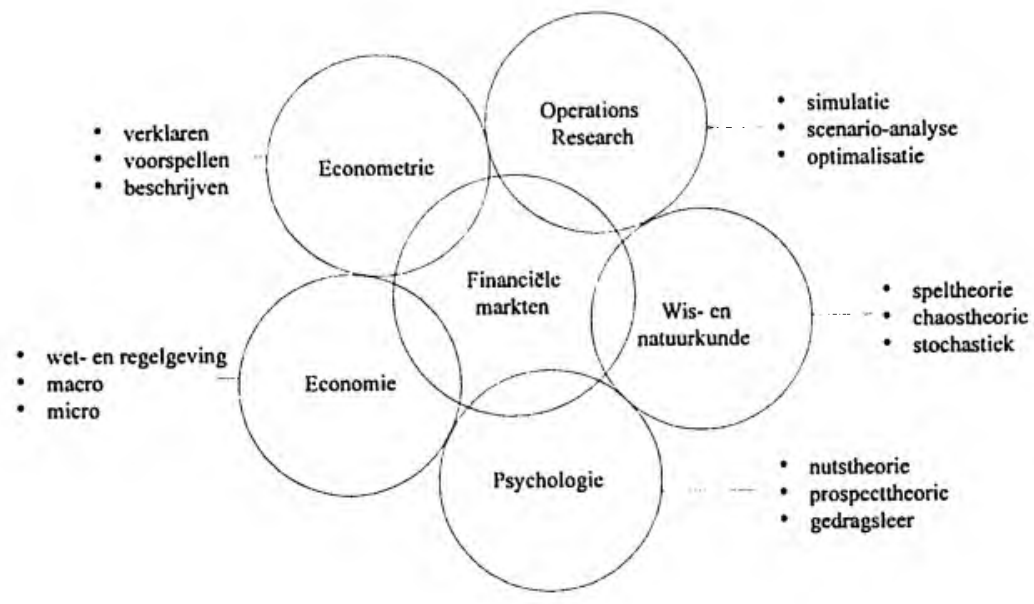

${ }_{16}$ Merk op dat voor de symmetrie van de figuur alle disciplines een even grote overlap met financiële markten zijn toebedeeld; dit is echter in de realiteit niet het geval. 
Zowel een belegger als modelbouwer vindt zijn of haar oorsprong in één van de disciplines die worden gebruikt binnen de financiële markten. Een grote mate van creativiteit heeft ertoe geleid dat binnen de financiële markten leentjebuur is gespeeld bij een fors aantal andere disciplines. De financiële aantrekkelijk van het vakgebied zorgt ervoor dat alle mogelijkheden worden onderzocht en uitgebuit.

In de figuur zien we ingrediënten terug die in het voorafgaande zijn besproken. Bijvoorbeeld worden vanuit de economie micro- en macro-economische variabelen aangedragen, die met behulp van econometrische voorspelmodellen kunnen worden omgezet in verwachtingen omtrent de koersontwikkcling op financiële markten. Met optimalisatieroutines uit de operations research kunnen vervolgens portefeuille-allocaties worden gemaakt. Nicuwe denkbeclden, zoals 'Behavioral Finance', vinden hun oorsprong in de psychologie. En, ten slotte, vormen de stochastische differentiaalvergelijkingen uit de wis- en natuurkunde de basis voor de prijsvorming van vele opties.

Uit de figuur volgt dat de traditionele splitsing tussen bedrijfs- en algemene economie en ook die tussen economie, econometrie en operations research vanuit de optiek van de financiële markten onnodig is. Sterker nog, voor het doen van vernieuwend onderzoek en voor het doceren van de nieuwe ontwikkelingen, kan de huidige opzet zoals die binnen de meeste economische faculteiten wordt gehanteerd wel eens verstikkend werken. Gelukkig zien we dan ook in toenemende mate een verbroedering tussen deze disciplines op het gebied van onderzoek en onderwijs, maar dit gaat in veel gevallen traag en 'hangt' op slechts enkele personen.

We zien ook dat er andere disciplines zijn terug te vinden: psychologie aan de ene kant en wis- en natuurkunde aan de andere kant. Onderzoek naar de werking van financiële markten is in deze disciplines minder expliciet ontwikkeld. Dientengevolge bieden deze disciplines nog ruimte voor interessant onderwijs en onderzoek. Ik pleit dan ook voor meer flexibiliteit ten aanzien van de studiemogelijkheden van de student, zodat hij of zij een hedendaags pakket kan samenstellen zonder dat structuren binnen de economische faculteit of in sommige gevallen zelfs universiteit belemmerend werken. 
Daarnaast kan ik het verband met de praktijk niet genoeg benadrukken. Ook hier zien we een tweetal ontwikkelingen die al een stap in de goede richting betekenen. Ten eerste vinden steeds meer studenten hun weg naar een stage op basis waarvan de doctoraalscriptie wordt geschreven. Voor de student is het goed om het geleerde in een praktijkomgeving toe te passen, maar ook voor de afnemer, die eenvoudig de nieuwste theoretische kennis in huis kan halen. Ten tweede zien we in de beleggingsleer steeds meer hoogleraren uit de praktijk, die met relevante probleemstellingen uit de praktijk een extra impuls aan academisch onderwijs en onderzoek kunnen geven. Maar ik zou verder willen gaan.

Niet alleen studenten zouden extra impulsen vanuit de praktijk moeten krijgen. Ook de wetenschappelijk medewerkers zouden meer in staat gesteld moeten worden om nieuwe ideec̈n uit de praktijk op te doen; de wisselwerking tussen theoric en praktijk kan bij een toegepaste wetenschap leiden tot actuele artikelen die in gerespecteerde tijdschriften gepubliceerd worden, en waar nog wat mee gedaan wordt ook. Een 'sabbatical year' zou één van de manieren kunnen zijn waarop de creativiteit van medewerkers een nieuwe impuls kan krijgen. In plaats van een tijdelijke verhuizing naar een andere universiteit zou het mogelijk moeten zijn een tijd te verkassen naar een financiële instelling; het geeft de wetenschappelijk medewerker de gelegenheid een tijdlang een kijkje te nemen in de keuken van de praktijk en het geeft de instelling de mogelijkheid te proeven aan de theoretische stand van zaken.

Ook het uitvoeren van adviesopdrachten vormt een vruchtbare manier voor de interactie tussen theorie en praklijk. Voor wetenschappelijk medewerkers is het wel mogelijk om dit te doen, maar door de discussie hieromtrent is dit soort werk - soms terecht, maar soms ook onterecht - in een kwaad daglicht komen te staan. Ik pleit dan ook voor een heldere, maatschappelijk aanvaardbare regeling met de juiste incentives voor alle betrokkenen. ${ }^{17}$ Niet primair omdat wetenschappers daar financieel wijzer van zouden worden, maar in de eerste plaats omdat dat de ontwikkeling van het vakgebied ten goede komt, zonder dat de reputatie van de wetenschapper in kwestie daarmee in het gedrang komt.

17 Hoewel de registratieregeling van nevenwerkzaamheden op een aantal universiteiten duidelijker is geworden na de bekende affaire, is de bescherming van de reputatie van de wetenschapper voor de publieke opinie met deze regeling niet gewaarborgd. 


\section{Conclusie}

De financiële markten zijn in de laatste dertig jaar zeer in omvang gegroeid en bovendien steeds complexer geworden. Ook de wetenschap heeft zich op dit punt sterk ontwikkeld en zodoende een grote stem gehad in de wijze waarop beleggers in de praktijk werken: steeds vaker verlangen klanten transparante en consistente beleggingsstijlen, die aan bepaalde relatieve rendementseisen voldoen. Dit vormt een ideale voedingsbodem voor het kwantitatief beleggen, dat daarom aan een onstuitbare opmars bezig is. Verstandig beleggen betekent hedentendage beleggen met kwantitatieve modellen ter ondersteuning van het beleggingsproces.

Op basis van nieuwe denkbeelden, die onderkennen dat mensen verschillende inzichten kunnen hebben over de prijsvorming op financiële markten, leeft nu ook vanuit de wetenschap de gedachte dat het mogelijk moet zijn de markt systematisch te verslaan. De voorspelmodellen hebben hierin een functie in die zin dat ze inzicht bieden in de variabelen die een rol spelen bij de bewegingen op financiële markten, mits er geen structurele veranderingen verwacht worden. Zoals altijd geldt: 'cen model is te mooi voor deze wereld', waardoor de kwalitatieve inzichten van een belegger nodig blijven om de uiteindelijke beleggingsbeslissingen te nemen.

Portefeuille-allocatiemodellen bieden de gelegenheid verwachtingen ten aanzien van beleggingsobjecten om te zetten in daadwerkelijke portefeuillegewichten, waarbij rekening wordt gehouden met allerlei specifieke wensen van de klant. De belangrijkste boodschap is dat deze modellen een zodanige functionaliteit moeten hebben dat ze in lijn liggen met de wijze waarop een belegger zijn besluiten neemt.

Beleggers uit de praktijk volgen de wetenschappelijke ontwikkelingen met grote belangstelling. Elke manier om nog beter te beleggen wordt aangegrepen. Dat legt een zware verantwoordelijkheid bij het academisch onderwijs en onderzoek. Student en wetenchappelijk medewerker zullen op de hoogte moeten zijn van problemen die in de praktijk als relevant worden ervaren. Ik pleit dan ook voor meer geïnstitutionaliseerde contacten tussen de universiteiten en de financiële instellingen. 


\section{Dankwoord}

Het is een goede gewoonte om aan het einde van een inaugurele rede een woord van dank te spreken tot een ieder die tot de hoogleraarsbenoeming heeft bijgedragen.

Mijnheer de Rector Magnificus, leden van het college van bestuur van de Rijksuniversiteit Limburg.

Ik ben $\mathrm{u}$ zeer erkentelijk voor de goedkeuring die u heeft willen hechten aan mijn benoeming tot hoogleraar Financieel Management en Financiële Markten cn dank u voor het in mij gestelde vertrouwen.

Hooggeleerde Wolff, beste Christiaan.

Mijn benoeming bewijst eens te meer dat het bezoeken van praktijkgerichte congressen tot inspirerende ideeën kan leiden. Jij hebt in betrekkelijk korte tijd een vakgroep neergezet die bij uitstek flexibel en resultaatgericht werkt en ik vind het een eer om hierin te mogen participeren. Ik dank je hiervoor hartelijk.

Geachte collega's op de universiteit.

In de afgelopen tijd heb ik reeds mogen ervaren hoe prettig het is om met jullie te werken. Ondanks mijn geringe aanwezigheid is het gezamenlijk verzorgen van onderwijs probleemloos verlopen. Bovendien is al op een natuurlijke wijze een nuttige uitwisseling van onderzoeksinzichten tot stand gekomen.

Geachte dames en heren studenten.

De toekomst van de financiële markten is aan jullie. Het biedt een uitdagend werkterrein dat hoge eisen stelt aan de kwaliteit van de opleiding. Mijn pleidooi voor meer interactie met de praktijk geldt in hoge mate voor jullie. Ik zal dan ook in mijn colleges pogen daar vorm aan te geven. 
Beste IRIS-collega's.

Het streven van de directie van het Institute for Research and Investment Services om een kwalitatief hoogwaardig onderzoekshuis te zijn en te blijven stelde mij in staat de academische ontwikkelingen wederom van dichtbij te volgen. Het enthousiasme waarmee de medewerkers van de afdeling Kwantitatief Onderzoek klaar stonden om mee te denken over het onderwijsmateriaal heeft mij door de drukke tijden heen geholpen. Ik dank jullie voor de steun.

Lieve familie en vrienden.

Jullie hebben vandaag zelf kunnen ervaren dat het Limburgse land de moeite waard is te bezoeken. Ik ben blij met jullie aanwezigheid nu en wellicht weer wat frequenter in de toekomst.

Lieve Aart, Bart en Iris.

Inspiratie, stimulans en liefde. Wat kan een mens nog meer verlangen?

Ik heb gezegd. 


\section{Verantwoording}

Ik wil op deze plaats Brigitte Slot en Gaston Siegelaer bedanken voor hun uitgebreide commentaar tijdens de voorbereiding van deze rede. Uiteraard ben ik zelf verantwoordelijk voor de inhoud van het eindprodukt.

Voorts dank ik Hans Schröder en Erik-Jan Jaquet voor de ondersteuning bij het tot stand komen van de publicatie. 


\section{Literatuur}

Arnott, R.D., 1988, The future for quantitative investment products, The Journal of Portfolio Management, winter, 52-56.

Arnott, R.D., 1994, Quantitative management in the coming decade, Financial Analysts Journal, May-June, 6-9.

Arnott, R.D. and R.D. Henriksson, 1989, A disciplined approach to global asset allocation, Financial Analysts Journal, March-April, 17-29.

Ball, R., S.P. Kothari and J. Shanken, 1995, Problems in measuring portfolio performance: An application to contrarian investment strategies, Journal of Financial Economics 38, 79-107.

Banz, R., 1981, The relationship between returns and market value of common stocks, Journal of Financial Economics 9, 3-18.

Brinson, G.P., L.R. Hood and G.L. Beebower, 1986, Determinants of portfolio performance, Financial Analysts Journal, July-August, 39-44.

Capaul, C., Rowley I. and W.F. Sharpe, 1993, International value and growth stock returns, Financial Analysts Journal, Jan-Feb, 27-36.

Chopra, V.K. and W.T. Ziemba, 1993, The effect of errors in means, variances and covariances on optimal portfolio choice, The Journal of Portfolio Management, winter, 6-11.

Copeland, T.E. and D. Mayers, 1982, The Value Line enigma (1965-1978): A case study of performance evaluation issues, Journal of Financial Economics, 289-321.

DeBondt, W.F.M. and R.H. Thaler, 1985, Does the stock market overreact?, Journal of Finance 40, 793-805.

DeBondt, W.F.M. and R.H. Thaler, 1994, Financial decision-making in markets and firms: A behavioral perspective, in: R. Jarrow, V. Maksimovic and W.T. Ziemba (eds.), Finance, Series of Handbooks in Operations Research and Management Science, North-Holland. 
De Jong, F., Kemna, A.G.Z. and T. Kloek, 1992, A Contribution to event study methodology with an application to the Dutch Stock Market, Journal of Banking and Finance 16, 11-36.

Fama, E.F., 1970, Efficient capital markets: a review of theory and empirical work, Journal of Finance 25, 383-417.

Fama, E.F. and K.R. French, 1992, The cross-section of expected stock returns, Journal of Finance 67, 427-465.

Fama, E.F. and J.D. MacBeth, 1973, Risk, Return, and Equilibrium: Empirical Tests, Journal of Political Economy 81, 607-636.

Ferson, W.E. and C.R. Harvey, 1991, Sources of Predictability in Portfolio Retums, Financial Analysts Journal, May-June, 49-56.

Ferson, W.E. and C.R. Harvey, 1994, Modelling the Fundamental Determinants of National Equity Market Returns, Working paper, Duke University.

Graham, B. and D. Dodd, 1934, Security Analysis, New York, McGrawHill.

Harvey, C.R., B. Solnik and G. Zhou, 1994, What determines Expected International Asset Returns?, Working paper, Duke University.

Jaffe, J., Keim. D.B. and R. Westerfield, 1989, Earnings yields, market values and stock returns, Journal of Finance 44, 135-148.

Keynes, J.M., 1936, The general theory of employment, interest and money, London: Harcourt Brace Jovanovich.

Kurz, M., 1994, Asset prices with rational beliefs, CEPR Publication \#375, Stanford University, forthcoming in Economic Theory.

Lakonishok, J., A. Shleifer and R.W. Vishny, 1994, Contrarian investment, extrapolation and risk, Journal of Finance 49, 1541-1578.

Lo, A. and A.C. MacKinley, 1990, Data-snooping biases in tests of financial asset pricing models, Review of Financial Studies 3, 431-467. 
Markowitz, H.M., 1959, Portfolio selection: Efficient diversification of investment, Wiley, New York.

Michaud, R.O., 1989, The Markowitz optimization enigma: Is "optimized" optimal?, Financial Analysts Journal 45, Jan-Feb, 31-42.

Reinganum, M., 1981, Misspecification of capital asset pricing: Empirical anomalies based on earnings yields and market values, Journal of Financial Economics 9, 19-46.

Sharpe, W.F., 1964, Capital asset prices: a theory of market equilibrium under conditions of risk, Journal of Finance, 425-442.

Shefrin, H. and M. Statman, 1994, Behavioral Portfolio Theory, Working Paper, Santa Clara University.

Shiller, R., 1981, Do stock prices move too much to be justified by subsequent changes in dividends?, American Economic Review 71, 421435.

Solnik, B., 1993, The performance of international asset allocation strategies using conditioning information, Journal of Empirical Finance 1, 33-55.

VandenBergh, W.M. and R.E. Wessels, 1985, Stock market seasonalities and taxes: An examination of the tax-loss selling hypothesis, Journal of Business Finance and Accounting 12, 515-530. 
Angelien Kemna (1957) studeerde bedrijfseconometrie aan de Erasmus Universiteit Rotterdam, gevolgd door een promotie in de Financiering en Beleggingen aan dezelfde universiteit.

Momenteel is zij hoofd van de afdeling Kwantitatief Onderzoek van het Institute for Research and Investment Services, een jointventure van Rabobank Nederland en de Robeco Groep. Met deze korte uiteenzetting over kwantitatief beleggen, aanvaardde zij het ambt van hoogleraar Financieel Management en Financiële Markten aan de Rijksuniversiteit Limburg. 